\title{
Inheritance of Folk Art in College Art Design Education
}

\author{
Weiwei Wang ${ }^{1}$ \\ ${ }^{1}$ Science and Technology College Gannan Normal University, Ganzhou, Jiangxi, 341000, China
}

\begin{abstract}
Nowadays, art design majors are offered in all art colleges and universities in China, but the students and teachers of this major often do not have a deep understanding of art design, which hinders the folk art inheritance of Chinese art design students. This paper explains folk art and art design, analyzes its characteristics, puts forward the problems of folk art inheritance in China, and puts forward the effective path of art design into folk art.
\end{abstract}

\section{Introduction}

Colleges and universities play an important role in the inheritance and development of Chinese traditional culture. Folk art, as a part of traditional culture, contains a variety of artistic forms. In addition to painting skills, folk art also includes calligraphy, paper-cut, porcelain and so on. As the expression of popular aesthetics, every skill in folk art condenses the wisdom of the masses. The crystallization of this wisdom should not disappear with the change of times. As a professional place for the dissemination of knowledge and culture, colleges and universities should give full play to the inheritance function of traditional culture so that students can cultivate their interest in folk art in their daily study, and make students realize the cultural background of this kind of folk art. In order to cultivate students correct aesthetic and values.

\section{Overview of Folk Art in China}

\subsection{What is Folk Art}

In Chinese historical development, the working people have created their own culture. Many ancient folk works of art are actually tools produced by people, or daily necessities. Therefore, folk art is the process of laboring people's invention and creation in life, is a manifestation of beauty. For example, the ancient palace wall and wall buildings and all beautiful daily necessities are the crystallization of the wisdom of the ancient working people, which can be collectively referred to as folk art. Of course, there are many people's daily life, can show the local customs and cultural characteristics. For example, paper-cut window flowers, folk sculpture, all these can reflect the uniqueness of folk art. Many folk artists take this as the source of ideas for creating works[1]. Whether ancient or modern, folk art is a kind of beautiful existence. It can flexibly integrate production technology and art perfectly. It not only forms a beautiful handicraft, but also can be used in real life.

\subsection{Characteristics of Folk Art in China}

The folk art of China has many characteristics, such as collectivity, inheritance, originality and so on.

\subsubsection{Collective:}

Chinese folk art has a certain collective nature. From ancient times to the present, our people have a strong artistic beauty in creating labor tools, daily necessities and architectural environment. Of course, these are inseparable from the crystallization of the wisdom of our working people. To complete the manufacture of these handicrafts, we can not do without the collective design and research of the working people of China, and finally make them. These step by step processes need to be completed collectively by the working people[2]. Only when the masses live together can people discover and make practical works of art with beautiful images in life. Therefore, collective life is the foundation of folk art design. Although many folk art is made by the same person, its purpose is to serve the society and the collective. Therefore, folk art is a collective art, not professional, nor is it made by professional artists, the economy is the integration of collective and individual producers. Therefore, the important characteristic of folk art is its collective characteristic.

\subsubsection{Inheritance:}

Chinese folk art also has strong inheritance characteristics. Under the crystallization of the wisdom of the working people in ancient times, later generations began to study folk art, and folk art also became the traditional culture of the Chinese nation. Therefore, folk art has a strong inheritance, later generations began to study what folk art is, and need to understand its essential spirit. Before the 
Song Dynasty, folk art was mainly passed on through the way of family. After the Song Dynasty, folk art began to spread a lot in society, so if folk art did not pass down the works, it would not be called folk art.

\section{An Overview of Art Design Education in Colleges and Universities}

At present, there are many art colleges and universities in China, and many art design majors have been set up. Art design is a professional noun. At present, many colleges and universities have set up this independent art subject. Students need to learn a lot of professional knowledge. Of course, art design also has many different directions, such as environmental design[3]. Graphic design, product design, etc. Therefore, art design is a mixed subject. And art design is the product of art beauty that people will feel in life, closely combined with the reality of life, showing it. Therefore, art design must serve the public, but also the inevitable product of contemporary social life. The following is a 17-year list of universities and colleges in China:

Table1. The ranking of Chinese University of Art in 2017

\begin{tabular}{|c|c|c|c|c|c|}
\hline position & school name & Region & National ranking & Star Rank & Level of running schools \\
\hline 1 & Hebei Media Institute & Hebei & 20 & 4 star level & China's High Level Private Universities \\
\hline 2 & $\begin{array}{c}\text { Shanghai Visual Arts } \\
\text { Institute }\end{array}$ & $\begin{array}{c}\text { Shangh } \\
\text { ai }\end{array}$ & 36 & 4 star level & China's High Level Private Universities \\
\hline 3 & Sichuan Media Institute & Szechwan & 44 & 4 star level & China's High Level Private Universities \\
\hline 4 & $\begin{array}{c}\text { Wuhan Institute of } \\
\text { Communication }\end{array}$ & Hubei & 52 & 3 star level & Famous Private University of China \\
\hline 5 & $\begin{array}{c}\text { Jilin Animation } \\
\text { Institute }\end{array}$ & Jilin & 61 & 3 star level & Famous Private University of China \\
\hline
\end{tabular}

Obviously, there are countless colleges and universities in art design in China, but the specialty of art design is not strong, the teachers are very weak, and the students and teachers' understanding of art design is not enough. There are still many problems in China in these aspects[4].

College art design has the following characteristics:

1) Service: As mentioned above, art design must serve the public, so the greatest characteristic of design is its service. You say that the purpose of design is not to show their own ideas, but to find a beautiful discovery of life, and creative change, clogs are to bring people a new way of life, to serve the people. On the basis of beauty, make life more simple and harmonious, this is the ultimate goal of art design.

2) Mixed: Art design is actually a highly mixed art subject, therefore, art design has a strong mixed characteristics. Art design involves a wide range of areas, including science, society, culture and so on. These factors affect each other and are independent of each other, and artistic design changes with the change of these factors[5].

\section{The Significance of Folk Art in Art Design Education in Colleges and Universities}

Folk art represents the wisdom of our working people from ancient times to the present. Folk art is very necessary in art design education in colleges and universities. Therefore, the inheritance of folk art is of great significance.

\subsection{Improving the aesthetic ability of students in art design}

Folk art has certain life significance, he is not only artistic, but also the physical embodiment of all kinds of beauty in life, so learning folk art can improve the aesthetic ability of Chinese students. To a certain extent, it shows the national characteristics and aesthetic concepts of different places in China. And if the child aesthetic training, can help children improve aesthetic ability. And folk art is not only a manifestation of beauty, but also emphasizes that the creator adds true feelings and has a certain human flavor. At the same time, this kind of folk art also expresses our working people's yearning for the beauty of life and the pursuit of all kinds of beautiful things in life.

\subsection{Improving students' creative ability in art design}

Learning folk art can improve the creative ability of art design students to a certain extent. Nowadays, folk art is an innovative folk art, no matter what kind of folk art, need a unique production technology and production techniques. Therefore, the idea of creating strange folk art is unique, which reflects the creative characteristics of folk art in China, and can effectively improve the creative ability of Chinese art design students.

\section{5 problems of folk art inheritance in China}

\subsection{Inadequate curriculum}

At present, all major art colleges and universities in China have art design courses, but the current social needs for talents can not be reflected in art design. After graduation, 
it is difficult for many students to find corresponding employment jobs. Therefore, it is difficult for colleges and universities to meet the standard. Therefore, the school in the art design professional course setting, there is a certain bias. Many excellent teachers can not be evenly distributed, many funny, still using a single teaching method, some ordinary college teachers' understanding of folk art is not comprehensive enough, therefore, Their teaching methods and curriculum have great problems[6].

\subsection{Teachers pay less attention to folk art}

In the modern art design education of China, at present, students do not know all kinds of folk art very well. This is also the major colleges and universities in China to the folk art curriculum is not standardized brought about by the problem. At the same time, the teachers of colleges and universities in China also have great defects in their understanding of folk art. They are not deep enough to master the works of folk art in China, and can not grasp the excellent traditional culture of China well[7]. Not to mention imparting this folk art to students. At the same time, teachers will also have some anxiety, because folk art is the traditional art of China, when students learn the idea of this traditional art, it is easy to disconnect from the current fashion design ideas. In fact, this kind of thing does not happen, because art is interlinked, and many ancient design ideas and ideas can also be applied to better inherit folk art. It is necessary to solve the problem of curriculum allocation and teacher training.

In modern design. Like the retro elements now, fashion is said to be a reincarnation. Often many Chinese traditional art production technology, after being passed on, after a reincarnation, will become the top fashion trend. This is why art is interlinked. At present, many students do not have enough understanding of our art works and can not deeply appreciate them. The most fundamental reason is that teachers do not have good training and students' creative level in the process of art education for students. In the teaching process, the teacher is only close to the teaching material, the content of the hypothesis is also the theoretical concept of the book, rarely combined with the actual experience of life. Therefore, students' understanding of folk art only stays on the surface. Teachers should combine their own experience, let students learn to feel beauty, appreciate beauty, identify beauty, discover beauty in life, and sentences let students design practice, give students their own feelings, and make the works more vivid. In order to improve the students' inheritance of folk art in China. Therefore, teachers play a key role in the inheritance of folk art[8].

\section{Inheritance Path of Folk Art in Art Design Education in Colleges and Universities}

In order to give full play to the advantages of our region and our school in the process of education, art colleges and universities must fully integrate and inherit folk art resources. Colleges and universities should give full play to the role of art education curriculum in the inheritance of folk art, through the rational construction of folk art in the process of art university education, so that folk art and college art education can be deeply integrated. In order to inherit folk art and carry forward our traditional culture laid the foundation.

\subsection{Setting up necessary elective courses and public appreciation courses.}

In the process of art education in colleges and universities, students should give full play to their main position of learning, so that students have the right and opportunity to choose the courses they like. Colleges and universities should scientifically plan the folk art resources owned by the region and effectively integrate these resources into the classroom of art education in colleges and universities. Colleges and universities should combine the actual needs of students, reasonable opening of folk art resources elective courses and public courses. In addition, college teachers play a major role in the inheritance and development of folk art culture in the region. Teachers should introduce to students the origin, development, history and inheritance of folk art in the classroom of art education. Teachers should enable students to understand and appreciate works of art from different angles, so that they can master the cultural connotations and changes of the times of related works, so as to further improve students' ability to appreciate art. Let students consciously cultivate the consciousness of protecting folk heritage culture[9].

\subsection{Building a Scientific Curriculum System}

As we all know, the core of college education lies in the construction of curriculum system. Therefore, in order to strengthen the inheritance of folk art in art education, art colleges and universities must reasonably plan and develop a scientific curriculum system of folk art teaching. At the same time, colleges and universities must have a plan, focus on the construction of professional, quality teachers. Colleges and universities should also give some support in teaching resources and funds to ensure that the construction of folk art resources curriculum can be continuously promoted. In the process of establishing folk art curriculum, teachers should develop and utilize relevant resources according to local conditions in combination with artistic characteristics and school needs. Teachers can continuously expand the scope of curriculum resources and carry out classroom teaching in stages and steps, so that art folk art resources can be continuously integrated into the teaching of various disciplines and specialties.

\subsection{Carrying out rich and colorful practical activities}

Rich and colorful practical activities can let students understand the specific folk art more deeply. Therefore, 
extracurricular practical activities must be targeted, it can be used as an extension of students to learn folk art. For example, shadow play, influenced by the diversity of science and technology and works of art, has become narrower and narrower in today's society. Instead of going to shadow play, people are more willing to watch related works of art through the Internet, cinemas and so on. Because of the complexity of the related characters in shadow play, fewer and fewer people now master this kind of production technology. However, as a major feature of folk art, shadow play can let students know more about our traditional skills. Therefore, college teachers should encourage students to further understand the traditional art by exploring, propagating and learning the production of shadow play villains. After the students finish their study and propaganda, the teacher should ask the students to write a detailed study report, elaborate the history, inheritance and current development state of shadow play, so that students can experience and feel the inheritance and development of shadow play in the process of practice. This can not only let students understand a skill, but also make students explore and perceive the traditional art culture more deeply[10].

\subsection{Strengthening the sense of inheritance of teachers and students}

Due to the influx of a large number of western aesthetic ideas into China in the last century, this has an important impact on the aesthetic outlook and values of Chinese teachers and students, which directly leads to the fact that Chinese folk art has not received due attention in the art education of colleges and universities. For example, in the art theory courses offered in colleges and universities, the proportion of traditional culture is very small. Many students do not realize folk art deeply or systematically in their daily courses, so they can not further explore the form and connotation of folk art. In order to accelerate the integration between folk art resources and art education, colleges and universities must objectively analyze and locate the connotation of folk art, so that students can realize the difference between western art and national art more objectively and clearly. College teachers should correctly guide students to objectively understand Chinese traditional folk art and its forms on the basis of learning and drawing lessons from western art, so that students can constantly optimize and promote folk art through professional study. In order to contribute to the development of folk art their own strength.

It is worth noting that folk art culture has a strong color, students should adhere to the spirit of criticism in the process of learning, and have a correct understanding of folk art on the basis of absorbing and accepting folk culture. In other words, in the process of learning folk art, teachers should encourage students to carry out critical thinking, take its essence, discard its dross, and ensure that students have a more objective and comprehensive understanding of folk art. Even in today's prevailing western culture, students still have a rational understanding of Chinese and Western art.

\section{CONCLUSION}

In a word, if we want to realize the inheritance of folk art in China, we need to solve the problem of teachers and students' understanding of folk art, set up more practical courses, not limited to the concept of books, change teachers' way of art design teaching, change teachers' understanding of folk art, cultivate and increase teachers' strength, so as to cultivate more outstanding talents of folk art, and finally increase inheritance and realize the high efficiency inheritance of folk art in art design education in colleges and universities.

\section{Author:}

Weiwei Wang(22 November 1981), gender: male, native: Longnan, Jiangxi, ethnic: Han, master's degree, lecturer, research field: fine arts, folk art.

\section{References}

1. Hu,S.T.(2014)Study on the inheritance of folk art in art design education. Hebei Normal University.

2. Ou,Y.M.(2015)Thoughts on introducing folk art into art design teaching in colleges and universities. Chongqing second normal College.

3. Yuan,H.X.Liu,X.J.(2008)Chinese folk art and art design teaching in colleges and universities. School of Art, Zhanjiang normal University.

4. Li,R.F.(2019)Inheritance and Innovation of Folk Art in Art Design Education in Colleges and Universities. Theatre House.

5. Niu,F.(2019)Study on Teaching Curriculum of Folk Art Design Education in Colleges and Universities. Smart times.

6. Zhang,X.H. Wei,H. Li,J.H. (2011) Thoughts on Integrating Local Folk Art into Art Design Education in Local Colleges and Universities. Science and Education Guide (last ten days).

7. Zhang,X.(2010)Innovation of Chinese Folk Art and College Art Education.Journal of Guilin Teachers College.

8. Xin,L.L.(2010)Inheritance and Development of Folk Art in Art Education in Local Colleges and Universities.Big stage.

9. Pan,M.(2009)Some Thoughts on Introducing Folk Art into Modern Teaching.Journal of Guizhou Institute for Nationalities (Philosophy and Social Sciences Edition).

10. Ping,A.(2004)How to Protect Folk Art __ Jinjing Exhibition of Shaanxi Excellent Folk Art Works "and" Symposium on the Protection and Promotion of Folk Art "in the face of crisis.Art Observation. 